\title{
Plant diversity and nutrient substances of native edible plant: Case study in Suka Maju and Tamao Villages, Kapuas Hulu District, West Kalimantan, Indonesia
}

\author{
SULVI PURWAYANTIE", URAI EDI SURYADI \\ Faculty of Agriculture, Universitas Tanjungpura. Jl. Prof. Dr. H. Hadari Nawawi, Pontianak 78124, West Kalimantan, Indonesia. \\ Tel.: +62-561-7053252, Fax.: +62-5610-740187, `email: sulvipurwayanti06@gmail.com
}

Manuscript received: 6 November 2019. Revision accepted: 31 January 2020

\begin{abstract}
Purwayantie S, Suryadi UE. 2020. Plant diversity and nutrient substances of native edible plant: Case study in Suka Maju and Tamao Villages, Kapuas Hulu District, West Kalimantan, Indonesia. Biodiversitas 21: 842-852. The existence of plant diversity which is wild, indigenous and edibles, needs to be preserved. The research locations in Suka Maju and Tamao Village, Kapuas Hulu District, West Kalimantan, Indonesia were chosen based on population density. The purpose of this study was to determine the plant diversity and nutritional potential from both of regions. The study method used purposive sampling survey and the data were analyzed descriptively. The results showed that from a total of 110 plants, the three local plant names were subjected to one species and nine species were found in both locations. So that from 98 plants consisting of 44 fruits ( 14 of table fruits and 30 fruits of suka-suka), 30 vegetables and mushrooms, 14 seasonings, 7 nuts, 3 cereals, and tuber. The discovery of rare genera reported from West Kalimantan, they are Hydnocarpus sp, Hodgsonia sp, and Hypoxylon spp. The highest proximate content of carbohydrate is from joluk kusuk seeds (C. lacryma jobil), fats from kepayang seeds ( $P$. edule) and dangkuk seeds (Hydnocarpus sp), protein from sengkubak leaves (A. papuana), ash from keranji (Hypoxylon spp) and dangkuk. The highest Fe and $\mathrm{Zn}$ mineral content were found from sengkuang fruit (D. dao) and tepus leaves (E. foetidum), respectively. The results of this survey became an initial recommendation in the development of local wisdom for local food security.
\end{abstract}

Keywords: Diversity, edible, indigenous, Kapuas Hulu, plant, wild

\section{INTRODUCTION}

Kapuas Hulu Regency has been known as a conservation district (PERDA Kabupaten Kapuas Hulu No. 20 2015). This is supported by the existence of Sentarum Lake and Betung Kerihun National Park and included as part of the 'Heart of Borneo'. Progressive developments in almost live fields can affect the sustainability of biodiversity (Suhartini 2009) that still exist until now. One thing that threatened is biodiversity as the spearhead of the main part to meet their daily needs (foods, medicine, buildings, culture, cosmetics). Although stated as a conservation district, not all areas in this district still have primary forest (BPS KH 2018). This is due to civilization development often making people turn to used unoriginal biological sources introduced from outside Kapuas Hulu. The introduction plants as a source of food in some areas never are avoided, but the wild plants as part of local wisdom should be developed increasingly became plants that have a similar minimum economic value like the plant as a source of food.

Meanwhile, Kapuas Hulu Regency is included in the area of accelerating the development of underdeveloped regions in 2015-2019 (Perpres RI No. 21 2018). One of the solutions to improvement and utilization of the potential resources of the forest areas and critical land by taking into account the principle of sustainable development. In the case of follow-up, there has been no report related to any action. This research was conducted to determine the potential of resources outside the forest area as a comparison, especially nutrient substances of native edible plant biological resources. It can be reported about the diversity of plants in the Kapuas Hulu Regency, few plants following the nutritional value relatively. Some survey reports on the same topic often mix between native edible and wild plants with the commerce food plants. e.g.: bananas, corn, kale, cassava, bitter melon, taro, etc. (Satrima et al. 2015; Haryanti et al. 2015; Pradityo et al. 2017). The Commerce of food sources is developed widely into the materials industry, so the existence of local wisdom based on the food sources needs to be informed about the benefits of it. Thus they could be developed into new food sources for the people of Indonesia. It is important to know that founding plant diversity has the potential to be developed into local food through cultivation and processing into economical food products.

For the global community, food based on local wisdom has become one of the requirements for of food in 2050 (Purwayantie 2019). Various food products based on local wisdom was developed into global products (Purwayantie 2019; Wibowo et al. 2019). The role of local universities together with the local community and the regional government of West Kalimantan is needed to highlight and develop the local wisdom to go international. Because of plant diversity from Kapuas Hulu's potential to promote to 
be ingredients of international culinary, biopharmaceutical, cosmetics for global communities. The results of this study became the recommendations for relevant stakeholders in developing local food that have the potential to improve local and national food security.

\section{MATERIALS AND METHODS}

\section{Study area}

Sampling locations were carried out by non-sampling surveys, namely in Suka Maju Village, Mentebah Subdistrict and Tamao Village, Embaloh Hulu Sub-district, Kapuas Hulu District, West Kalimantan Province. Selecting a location based on the location of dense forests in Kapuas Hulu District because at the area is easy to find the diversity of plants and the area is not dense of population.

Based on the map of survey location (Figure 1), the dense population area can be shown in orange and yellow while the light green colors indicate the forest area. In this activity, the dense area is highly populated. Because of the dense area, there are a lot of agricultural lands were cultivated in that location. Therefore, the area was not chosen as the location of the activity. From Figure 1. it can be seen that the dense area starting from the border of
Sintang District to the Hulu Gurung Sub-district[W1] (pastel color, west and south of Kapuas Hulu ). Mentebah Sub-district is located near the middle of the Hulu Gurung Sub-district and Putussibau City, it is marked by light green area on the map, namely the dryland forest. The population density in Mentebah Sub-district, particularly in Suka Maju Village has a relatively moderate population density (17.47/km2; (BPS 2019) with a high population from residents in the Sub-district city. Suka Maju village located in 0711070 longitudes and 0058474 latitudes (49N). Generally, the plant diversity in adjacent areas has same plant diversity profile. Therefore, another sample from Embaloh Hulu Sub-district was taken further from location I (Mentebah). This Sub-district is an area in the wetland forest area and Tamao Village has the lowest population density $\left(1.03 / \mathrm{km}^{2}\right.$; BPS 2019) compared to other villages in the same of Sub-district (dark green color). Tamao village located in 0658091 longitudes and 0125041 latitudes $(49 \mathrm{~N})$. The area at the center of the district, especially around the Sentarum Lake, was not selected as a survey area because it is a protected area, swamp, peat soils, and the materials for research difficult to find. Material collection in the two villages is not from the primary forest area or Forest Management Unit area but starts from the yard as the secondary forest.

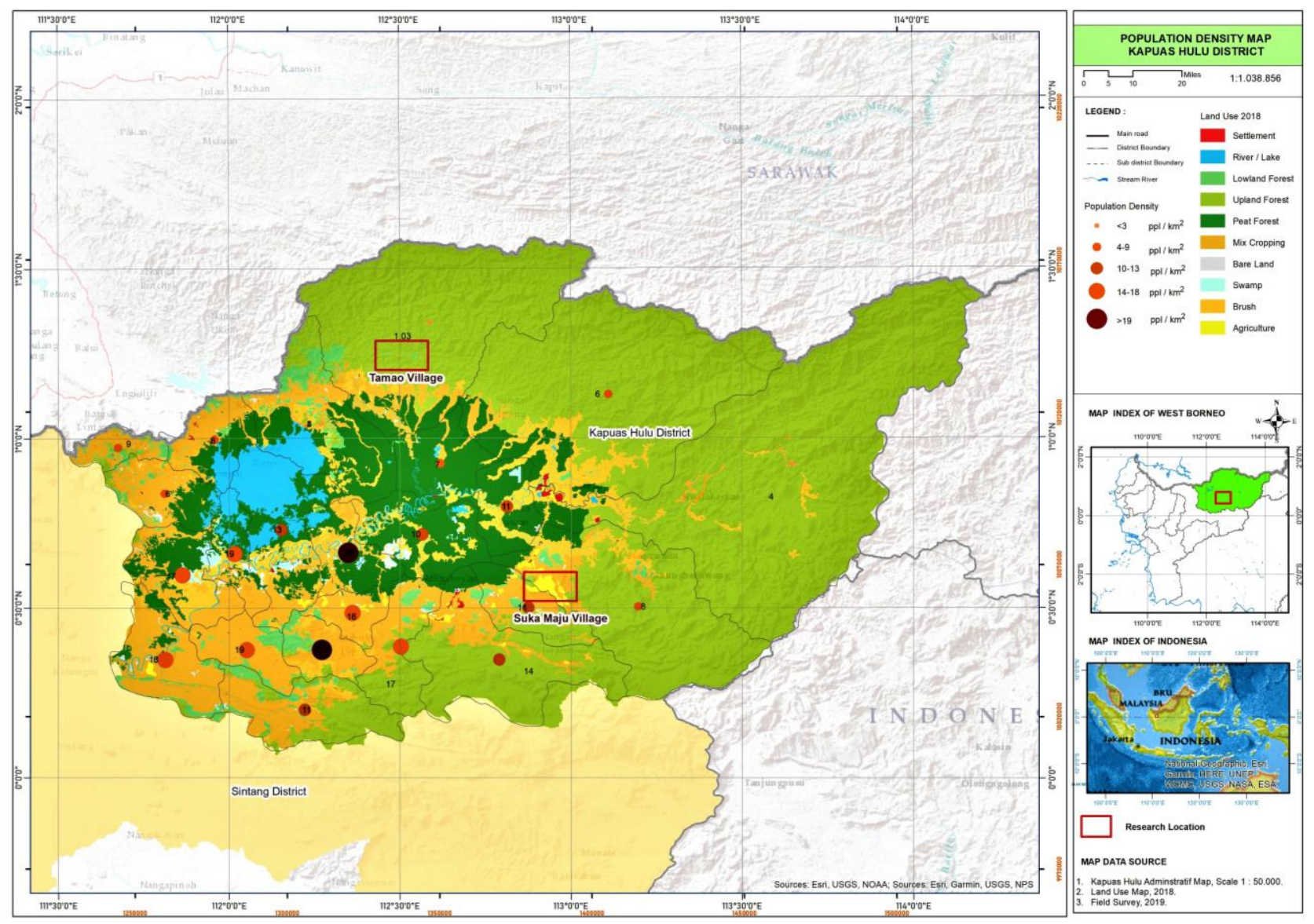

Figure 1. Survey locations in Suka Maju Village (Mentebah Sub-district) and Tamao Village (Embaloh Hulu Sub-district), Kapuas Hulu District, West Kalimantan, Indonesia 


\section{Selection of respondents}

The selection of respondents is an important component of this activity. The respondents were determined based on recommendations from the local traditional leaders and all other information that found during the preliminary survey. In this activity, the respondent is the person who is asked to provide all the information concerning the intended plant including the location of the plant, utilization of the plant, local name, as well as all facts or opinions related to the intended plant. The information can be conveyed in written form when filling out a questionnaire or verbally. In addition to the answer to the questions from questionnaires given by respondents also followed by the survey team to inform and about the location of the plant growth is mentioned.

\section{Data collection techniques}

This study used a survey method for conducting the research. The researcher collected the data collection. The data was taken from direct interviews, questionnaires, documentation, and identifying plants with help from Herbarium Bogoriense, Research Centre for Biology, Indonesian Institute of Sciences (LIPI), Cibinong, Bogor, Indonesia.

\section{Chemical analysis methods}

The chemical analysis includes proximate (AOAC 2006), fiber (Sudarmadji 2007), calories (Sukasih and Setyadi 2017) and minerals using AAS (Subramanian et al. 2012). Not all proximate analysis is done because not all materials are available when the survey is conducted (not yet bearing fruit) or the quantity submitted by the community is not sufficient in quantity to be analyzed. The results of the proximate analysis are still rough because they do not directly reflect the intended nutrients. The value of protein produced through the Kjedhal method calculates only the total value of $\mathrm{N}$ while the $\mathrm{N}$ in food does not only come from protein but includes $\mathrm{N}$ in the alkaloids and nucleotides. The value of fat produced through the Soxhlet method calculates as total lipids (all chemical compounds that are not soluble in water) without knowing the actual fat/oil content. The value of carbohydrates is produced from calculations by different material is considered to have a value of $100 \%$, then the value of carbohydrates is $100 \%$ minus the percentage value of moisture, ash, fat, and protein.

The mineral analysis has functions specifically in the physiology of the human body such as macro minerals $(\mathrm{P}$, $\mathrm{Mg}, \mathrm{Na}, \mathrm{Ca}$ ) and micro minerals (Fe, $\mathrm{Zn}, \mathrm{Cu}$ ). The calories were measured by conversion factors for protein $(4 \mathrm{kcal} / \mathrm{g})$, fat $(9 \mathrm{kcal} / \mathrm{g})$ and carbohydrate $(4 \mathrm{kcal} / \mathrm{g})$.

\section{Data analysis}

In this study, the researcher used some technique for processing the data, there are editing (reducing) the data, and displaying the data descriptively.

\section{RESULTS AND DISCUSSION}

\section{Plant identification}

The identification of plant diversity wild plant and native edible plants in two villages was found a total of 24 genera, 70 species, and 11 unidentified plants. In Mentebah Sub-district has been found unknown 17 genera, 55 species and 11 of plants, while from Embaloh Hulu Sub-district, there are unknown 7 genera, 15 species and 5 of plants. This result based on the example of bark specimens that cannot be tested at LIPI as an alternative to immature fruit. From the two districts, there are 9 species that are same, they are patikala/kecombrang (E. elatior) sour fruits, tepus (E. foetidum) leaf, tugu/sengkubak (A. papuana) leaf, empakan/papakan (D.kutejensis), mawang/imbawang (M. pajang) sour fruit, keriang/riang acid leaf, kuranji (D. indum) sour fruit, cengkodok (M. malabatricum), cempedak (A. champeden. From the total 101 of wild plants, native edible plants has been found, classified into 5 of food groups (Figure 2).

According to residents, there is a fruit group that can be consumed when in the forest, field farms or by hunter, they do not bring at home or sold. The fruit group was called the 'suka-suka' fruits, so the total number of food groups were6 groups. The complete number of plants found can be seen in Table 1. There are 98 species were found and unreported from West Kalimantan are dangkuk fruit (Hydnocarpus sp.), dendang pumpkin (Hodgsonia macrocarpa), and mushrooms (Hypoxilon sp.) (Figure 3, 4 and 5). There has been reported in Flora Malesiana that only one species Hodgsonia macrocarpa in Borneo (de Wilde and Duyfjes 2010) but there is no explanation that the species found in west, centre, south or east of Borneo (Kalimantan). These three genera are only found in Mentebah Sub-district, both types of fruit and mushrooms are used by a few people and some never known, while the keranji mushroom is eaten by some residents who are going to the forest every day.

Mushroom types from genera Hypoxylon and Xylaria have been reported to be found in Malaysia with each Hypoxylon (17 sp.) and Xylaria (47 sp.) spread across the peninsula of Malacca to Sarawak. Some names of Hypoxylon fungi are combined with the name Xylaria, for example, $H$. avellana same as $X$. avellana (Lee et al. 2012).

\section{Proximate and calories}

The nutritional composition of several wild plants, indigenous, edible and wild biodiversity found in The Mentebah Sub-district and Embaloh Hulu Sub-district can be seen in Table 2 .

\section{Mineral composition}

Mineral composition derived from the ash content. The specific mineral compositions in several wilds, native edible plants edible from Suka Maju and Tamao Villages can be seen in Table 4. 
Table 1. The genera and species found in Suka Maju and Tamao Villages, Kapuas Hulu District, West Kalimantan, Indonesia

\begin{tabular}{|c|c|c|c|}
\hline Local/vernacular name & Genera or species name & Famili & Location \\
\hline Abok putih & Ipomea cf. gracilis $\mathrm{R}$. Brown. & Convolvulaceae & Mentebah \\
\hline Asam kala/patikala fruit & Etlingera elatior (Jack) R. M. Smith. & Zingiberaceae & Mentebah \\
\hline Kandis acid fruit & Garcinia xanthochymus Hook. f. ex T. Anderson & Clusiaceae & Mentebah \\
\hline Keriang acid leaf & Begonia bracteata Jack. & Begonia ceae & Mentebah \\
\hline Pelanduk acid fruit & Baccaurea racemose Muell. Arg. & Phyllanthacae & Mentebah \\
\hline Tabar acid fruit & Costus sp. & Zingiberaceae & Mentebah \\
\hline Keranji acid fruit & Dialium indum L., Mant. & Caesalpinioideae & Mentebah \\
\hline Mawang acid fruit & Mangifera pajang Kostermann. & Anacardiaceae & Mentebah \\
\hline Kepayang seeds & Pangium edule Reinw. & Achariaceae & Mentebah \\
\hline Kerantik seeds & Lepisanthes sp. & Sapindaceae & Mentebah \\
\hline Kenual seeds & - & - & Mentebah \\
\hline Bebek fruit & Saurauia nudiflora DC. & Actinidiaceae & Mentebah \\
\hline Engkuis/Cat eye fruit & Dimocarpus longan Lour. & Sapindaceae & Mentebah \\
\hline Kumpang fruit & Horsfieldia irya (Gaertn.) Warb. & Myristicaceae & Mentebah \\
\hline Laki fruit & - & - & Mentebah \\
\hline Lemba fruit & Curculigo latifolia Dryand. & Hypoxidaceae & Mentebah \\
\hline Lepang fruit & Gymnopetalum cochinensis (Lour) Kurz & Cucurbitaceae & Mentebah \\
\hline Lupun fruit & - & - & Mentebah \\
\hline Ombak fruit & Baccaurea macrocarpa (Miq.) Mull. Arg. & Phyllanthaceae & Mentebah \\
\hline Rumbai fruit & - & Phyllanthaceae & Mentebah \\
\hline Sengkuang fruit & Dracontomelon dao (Blanco) Merr. \& Rolfe. & Anacardiaceae & Mentebah \\
\hline Sindu akar fruit & Scorodocarpus borneensis Becc. & Olacaceae & Mentebah \\
\hline Sindu api fruit & Scorodocarpus borneensis Becc. & Olacaceae & Mentebah \\
\hline Temeranau fruit & Durio dulcis Becc. & Malvaceae & Mentebah \\
\hline Cengkodok fruit & Melastoma malabatricum $\mathrm{L}$. & Melastomaceae & Mentebah \\
\hline Cempedak fruit & Artocarpus champeden (Lour.) Stokes. & Moraceae & Mentebah \\
\hline Cuncun fruit & Zingiber sp. & Zingiberaceae & Mentebah \\
\hline Dadak & Sloetia elongats Koord. & Moraceae & Mentebah \\
\hline Dangkuk seeds & Hydnocarpus sp. & Achariaceae & Mentebah \\
\hline Kesepang leaf & Antidesma sp. & Phyllanthaceae & Mentebah \\
\hline Kondang leaf & Ficus variegata Blume. & Moraceae & Mentebah \\
\hline Sengkubak leaf & Albertisia papuana Becc. & Menispermaceae & Mentebah \\
\hline Tepus leaf & Eryngium foetidum Linn. & Apiaceae & Mentebah \\
\hline Engkala fruit & Litsea garciae Vidal. & Lauraceae & Mentebah \\
\hline Empakan fruit & Durio kutejensis Hassk. Becc. & Bombacaceae & Mentebah \\
\hline Empauh fruit & Baccaurea lanceolate (Miq.) Müll. Arg. & Phyllanthaceae & Mentebah \\
\hline Emperingat fruit & Rubus moluccanus Linn. & Rosaceae & Mentebah \\
\hline Enceriak fruit & - & - & Mentebah \\
\hline Jambu monyet fruit & Bellucia pentamera Naudin. & Melastomataceae & Mentebah \\
\hline Joli' kusuk seeds & Coix lacryma-jobi Linn. & Poaceae & Mentebah \\
\hline Jewawut seeds & Setaria sp. & Poaceae & Mentebah \\
\hline Kasai fruit & Pometia pinnata Forst \& Forst. & Sapindaceae & Mentebah \\
\hline Kecombrang flower & Etlingera elatior (Jack) R. M. Smith. & Zingiberaceae & Mentebah \\
\hline Kemayong fruit & Salacca $\mathrm{sp}$. & Arecaceae & Mentebah \\
\hline Kemayao fruit & Dacryodes rostrate Blume. & Burseraceae & Mentebah \\
\hline Kelampai seeds & Elateriospermum tapos Blume. & Euphorbiaceae & Mentebah \\
\hline Beruk mushroom & Stereum spp. & Stereaceae & Mentebah \\
\hline Gelang mushroom & Lentinus sajorcaju (Fr.) Fr. & Polyporaceae & Mentebah \\
\hline Black mushroom & Lentinus spp. & Polyporaceae & Mentebah \\
\hline Insang mushroom & Tremella spp. & Tremellaceae & Mentebah \\
\hline Keranji mushroom & Hypoxylon spp. & Hypoxylaceae & Mentebah \\
\hline Korup mushroom & Auricularia delicata (Fr.) Henn. & Auriculariaceae & Mentebah \\
\hline Embibir mushroom & Auricularia auricula-judae (Bull.) & Auriculariaceae & Mentebah \\
\hline Lapek mushroom & Auricularia polytricha Linn. & Auriculariaceae & Mentebah \\
\hline Honey mushroom & Xeromphalina spp. & Tricholomataceae & Mentebah \\
\hline Cup mushroom & Cookeina sulcipes (Berk.) Kuntze. & Sarcoscyphaceae & Mentebah \\
\hline Sweet mushroom & - & - & Mentebah \\
\hline Fish eye mushroom & - & - & Mentebah \\
\hline Nyamuk mushroom & Marasmius spp. & Marasmiaceae & Mentebah \\
\hline Nyonya mushroom & Laetiporus spp. & Fomitopsidaceae & Mentebah \\
\hline White mushroom & Pleurotus astreatus (Jacq.) P. Kumm. & Pleurotaceae & Mentebah \\
\hline Tawon mushroom & Schizophyllum commune Fries. & Schizophyllaceae & Mentebah \\
\hline Labu dendang seeds & Hodgsonia macrocarpa Blume & Cucurbitaceae & Mentebah \\
\hline
\end{tabular}




\begin{tabular}{|c|c|}
\hline Lagan & Plagiostachys crocydocalyx (K.Schum.) \\
\hline Lasikan & Baccaureae macrophylla (Müll.Arg.) \\
\hline Linang fruit & - \\
\hline Malamun & Nephellium sp. \\
\hline Mentawak fruit & Artocarpus anisophyllus Miq. \\
\hline Mintau fruit & - \\
\hline Pelajau seeds & Pentaspadon motley Hook.f. \\
\hline Petai aek seeds & Archidendron fagifolium Miq. \\
\hline Bamboo shoots & Dendrocalamus asper (Schult. \& Schult. f.) \\
\hline White tampoi fruit & Baccaurea macrocarpa (Miq.) Mull.Arg. \\
\hline Tebu telo' & Saccharum edule Hasskarl. \\
\hline Acid Terong (yellow) & Solanum ferox Linn. \\
\hline Oval Terong (white) & Solanum melongena Linn. \\
\hline Purple Terong (small) & Solanum melongena Linn. \\
\hline Tiтаu & Ficus uncinata (King) Becc. \\
\hline Ubar & Syzygium polyanthum (Wight) Walp. \\
\hline Ubar Serai & - \\
\hline Umbing fruit & Baccaurea angulata Merr. \\
\hline Rotan shoots & Dendrocalamus latiflorus Munro. \\
\hline Kelapa mushroom & - \\
\hline Pelanduk eye mushroom & Calostoma spp. \\
\hline Andunge fruit & Salacca sp. \\
\hline Aratak binung & Abelmoschus esculentus (L.) Moench. \\
\hline Riang acid leaf & Begonia bracteata Jack. \\
\hline Kandis acid fruit & Garcinia xanthochymus Hook.f. \\
\hline Aung fruit & Mangifera sp. \\
\hline Kembayau seeds & Dacryodes rostrate (Blume) H.J.Lam. \\
\hline Litakan fruit & Willughbeia angustifolia Miq. \\
\hline Suntet fruit & - \\
\hline Cempedak fruit & Artocarpus champeden (Lour.) Stokes. \\
\hline Dabai/Pansaan seeds & Canarium odontophyllum Miq. \\
\hline Buas-buas/singkil leaf & Premma cordiflora Roxb. \\
\hline Pengo leaf & - \\
\hline Tepus leaf & Eryngium foetidum Linn. \\
\hline Tugu leaf & Albertisia papuana Becc. \\
\hline Garinis leaf & Licuala sp. \\
\hline Imbawang fruit & Mangifera pajang Kostermann. \\
\hline Kalong mangoa fruit & Nephellium sp. \\
\hline Basi mushroom & - \\
\hline Talingo balau mushroom & Auricularia fuscosuccinea (Mont.) Henn. \\
\hline Lalis leaf & Plectocomiopsis geminiflora (Griff.) Becc. \\
\hline Limudan fruit & Salacca sp. \\
\hline Mao fruit & - \\
\hline Papa Ulu fruit & - \\
\hline Papakan fruit & Durio kutejensis Hassk. Becc. \\
\hline Tatolok fruit & Garcinia dioica Bluem. \\
\hline Tambuk payang fruit & Mangifera sp. \\
\hline Kecombrang flower & Etlingera elatior (Jack) R. M. Smith. \\
\hline Kala acid fruit & Etlingera elatior (Jack) R. M. Smith. \\
\hline
\end{tabular}

\begin{tabular}{|c|c|}
\hline Zingiberaceae & Mentebal \\
\hline Phyllanthaceae & Mentebal \\
\hline- & Mentebal \\
\hline Sapindaceae & Mentebal \\
\hline Moraceae & Mentebal \\
\hline- & Mentebal \\
\hline Anacardiaceae & Mentebal \\
\hline Fabaceae & Menteba \\
\hline Poaceae & Menteba \\
\hline Phyllanthaceae & Menteba \\
\hline Poaceae & Menteba \\
\hline Solanaceae & Menteba \\
\hline Solanaceae & Menteba \\
\hline Solanaceae & Menteba \\
\hline Moraceae & Menteba \\
\hline Myrtaceae & Menteba \\
\hline- & Menteba \\
\hline Phyllanthaceae & Menteba \\
\hline Poaceae & Menteba \\
\hline- & Menteb \\
\hline Calostomaceae & Menteb \\
\hline Palmae/aracaceae & Tamao \\
\hline Malvaceae & Tamao \\
\hline Begoniaceae & Tamao \\
\hline Clusiaceae & Tamao \\
\hline Sapindaceae & Tamao \\
\hline Burseraceae & Tamao \\
\hline Apocynaceae & Tamao \\
\hline- & Tamao \\
\hline Moraceaa & Tamao \\
\hline Burseraceae & Tamao \\
\hline Lamiaceae & Tamao \\
\hline- & Tamao \\
\hline Apiaceae & Tamao \\
\hline Menispermaceae & Tamao \\
\hline Palmae & Tamao \\
\hline Anacardiaceae & Tamao \\
\hline Sapindaceae & Tamao \\
\hline- & Tamao \\
\hline Auriculariaceae & Tamao \\
\hline Palmae & Tamao \\
\hline Palmae/Arecaceae & Tamao \\
\hline- & Tamao \\
\hline Palmae/Aracaceae & Tamao \\
\hline Bombacaceae & Tamao \\
\hline Clusiaceae & Tamao \\
\hline Anacardiaceae & Tamao \\
\hline Zingiberaceae & Tamao \\
\hline Zingiberaceae & Tamao \\
\hline
\end{tabular}

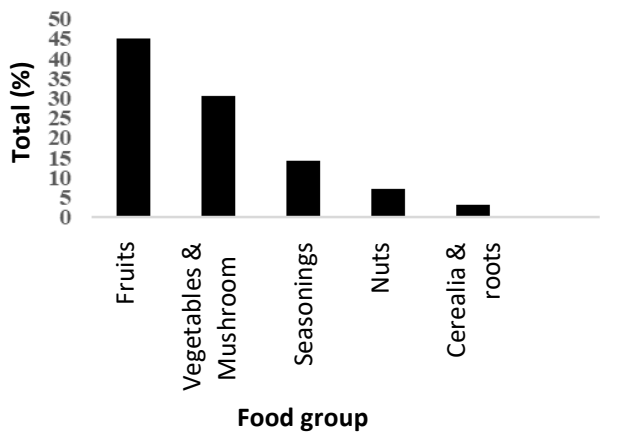

Figure 2. Total of wild plants, native edible plants from Suka Maju and Tamao Villages, Kapuas Hulu District, Indonesia

\section{Discussion \\ Identification of plant diversity}

The number of species found in the Mentebah Subdistrict is greater than the Embaloh Hulu Sub-district. This is due to the limitation survey area in Embaloh Hulu because the observation area is located in the Forest Management Unit so the observation is only around the yard of the house. However, all plant diversity found in Tamao Village according to the author is the result of in situ conservation because the residents say that someday the residents will run out of the substances. To overcome the situation seeds are taken from the forest and planted in the yard. The resident-only planted the seeds and not taking care of them. Moreover, the location of the yard becomes a 
secondary forest.

Due to the plant diversity types are almost similar in both villages, only a few species were not found in Suka Maju Village, moreover, the researcher thought from Table 1 the biodiversity types that are rarely reported from Kapuas Hulu District. Except for the three genera mentioned before, the same type of plant diversity of food crops has been widely reported from Kapuas Hulu District but there is no data of nutritional content (Satrima et al. 2015; Haryanti et al. 2015; Pradityo et al. 2017).

\section{Dangkuk fruit (Hydnocarpus sp.)}

In the beginning, people ignore dangkuk fruit because they do not know the benefits of it. In fact, the existence in that area is abundant according to the story, from the people who consumed the fruit. The team tried the fruit and the taste like coconut, they did not feel any side effects from consuming the fruit, so the samples can be sent to LIPI. This type of Hydnocarpus $s p$ is rarely published from Kapuas Hulu District. Hydnocarpus sp species H. woodii, $H$. kunstleri, $H$. anomala, $H$. gracilis were reported in East Kalimantan (Kartawinata et al. 2006) including $H$. heterophylla and $H$. polypetala (Angriyanti 2010). Species of Hydnocarpus sp. also found in Central Kalimantan and referred to orangutan food (Nayasilana et al. 2017).

The Hydnocarpus species produces chaulmoogra oil for healing leprosy and other skin diseases (Rameshkumar et al. 2011; Parascandola 2003; Cole 1933). The species that have high content of chaulmoogra oil are from $H$. wightianus species. Besides Hydnocarpus seeds producing oil, it was reported by (Dhathri 2011) that $H$. petandara oil can be made into biodiesel. Dhanasekaran et al. (2013) also mentioned that seeds of the genera Hydrocarpus sp. are rich in nutrients and phytochemicals (sterols, flavonoids, flavonolignans). The type of flavonolignan is hydnocarpin which has been reported to have antimicrobial, antitubercular, antipsoriatic, antirheumatic, hypolipidemic, antidiabetic, anti-inflammatory, andantanthidid activity. In addition to the seeds, leaves of the $H$. petandra by Kekuda et al. (2017) reported that it has contained phytochemicals such as essential oils, alkaloids, tannins, triterpenes, phenolics. Mentioned in Varghese et al. (2016) the genera Hydrocarpus is generally used to prevent skin diseases. Therefore, the hydrocarpus type of Kapuas Hulu is worthy of research and development into functional food and medicinal ingredients.

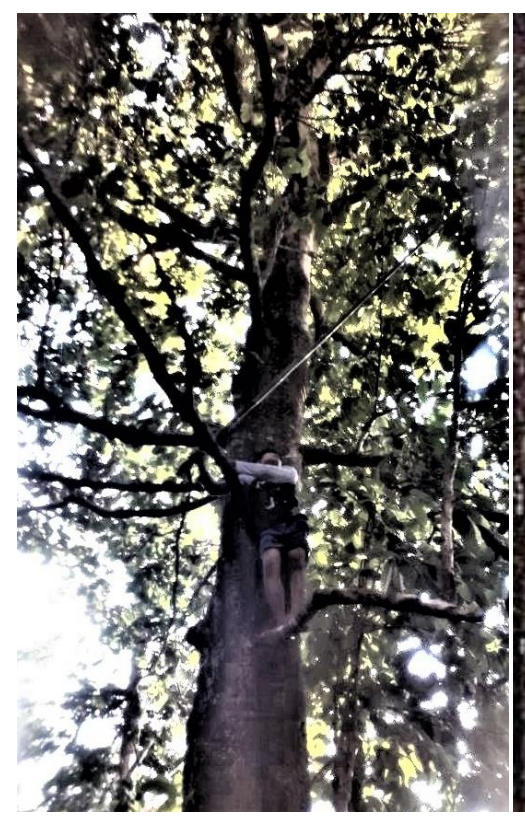

$\mathbf{A}$

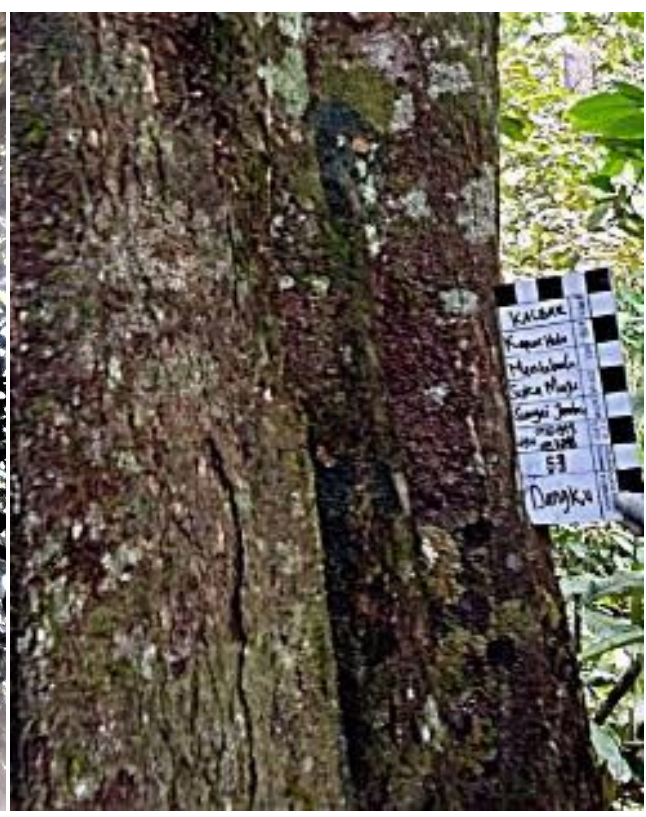

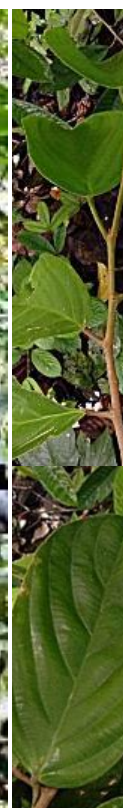

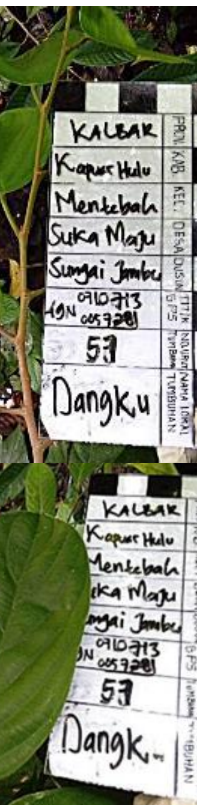

$\mathbf{C}$

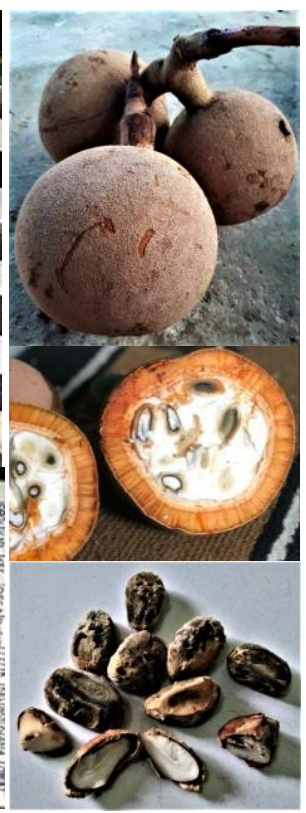

D

Figure 3. A. Dangkuk (Hydnocarpus sp.) trees, B. Bark, C. Leaves, D. Young fruit and seeds

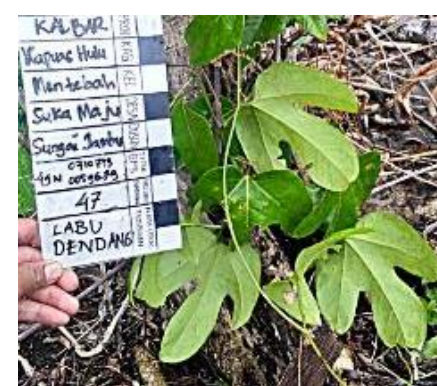

A

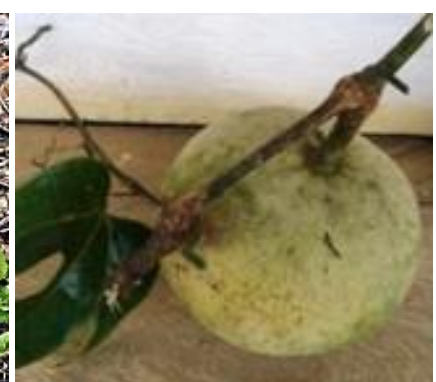

B

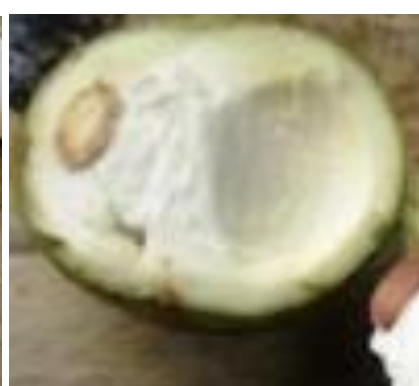

C

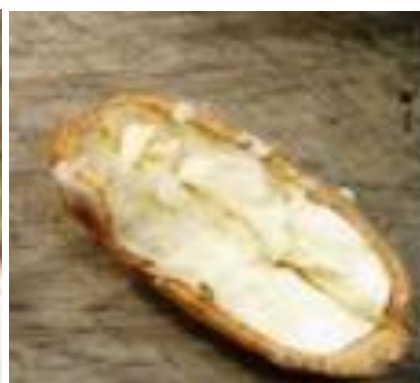

D

Figure 4. A. Dendang (Hodgsonia macrocarpa) pumpkin, B-C. Young fruits, D. Seeds 

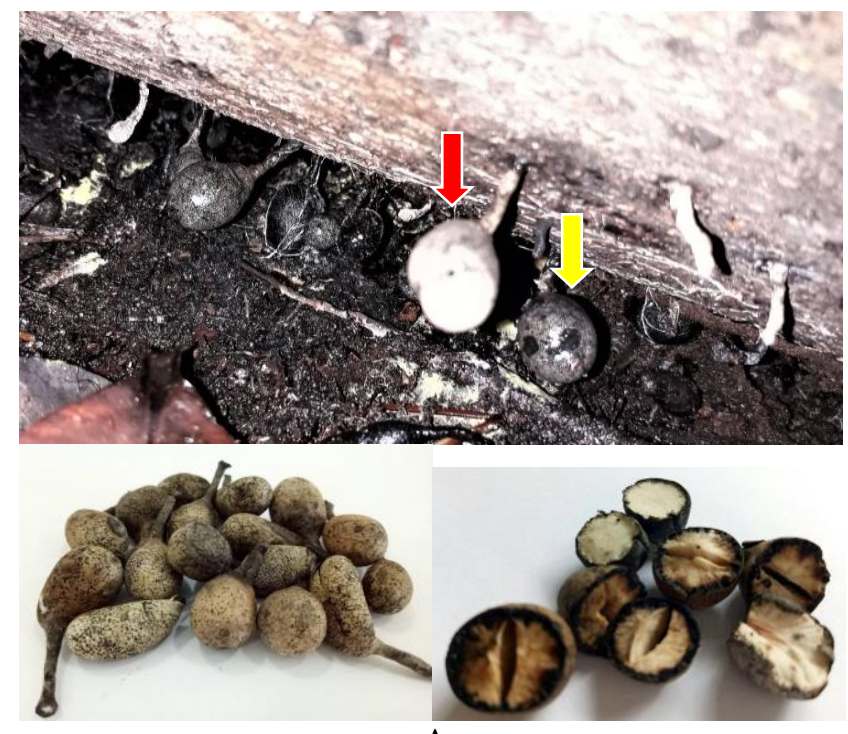

A

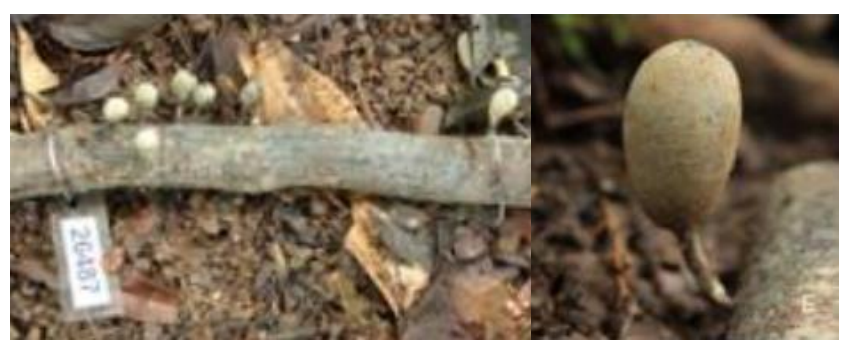

$\mathbf{B}$

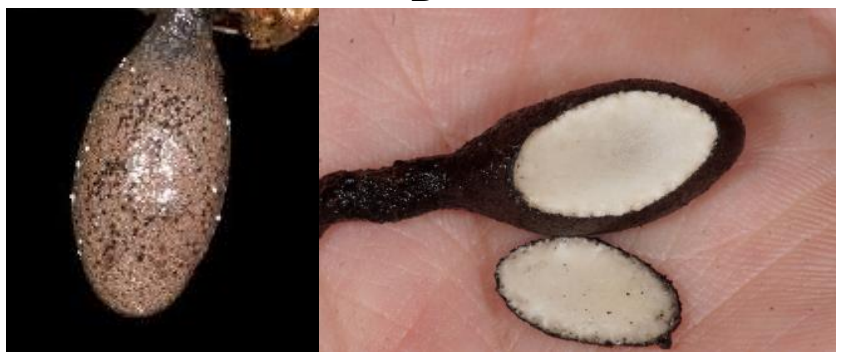

C

Figure 5. A.Keranji mushroom (Hypoxylon spp); white (young mushroom, red arrow) and black (old mushroom, yellow arrow), and profiles in oven-dried young mushrooms; B. Xylaria fockei and C. Xylaria schweinitzi

Table 2. Hypalon and Xylaria mushroom types found in Malaysia (Lee et al. 2012)

\begin{tabular}{|c|c|c|c|}
\hline Hypoxyloneceae & Xylariaceae & & \\
\hline H. anthracodes & X. acicula & $X$. fissilis & X. oligotoma \\
\hline H. approximans & $X$. acicularis & $X$. fockei & X. plebeja \\
\hline H. coelatum & $X$. allantoidea & $X$. fraseri & X. polyclada \\
\hline H. cohaerens & $X$. avellana & $X$. furcate & X. polymorpha \\
\hline H. comedens & X. axifera & $X$. gigantean & X. rhizocola \\
\hline H. howeanum & X. berkeleyi & $X$. gracilis & X. rhizomorphs \\
\hline H. lenormandii & X. caespitulosa & $X$. guepinin & $X$. ridleyi \\
\hline H. macrocenangium & X. complanata & $X$. guianensis & X. schweinitzii \\
\hline H. microsporum & $X$. corniformis & $X$. holobapha & X. scopiformis \\
\hline H. ochraceum & X. cupressiformis & $X$. hypxylon & \\
\hline H. pauxillum & $X$. cynoglossa & X. ianthinoveluntina & \\
\hline H. pseudotubulina & $X$. deserticola & $X$. intermedia & \\
\hline H. rubiginosum & $X$. dichotoma & $X$. kedahae & \\
\hline H. stygium & $X$. digitata & X. maraca & \\
\hline H. subgilvum & $X$. emerici & X. masuula & \\
\hline H. tinctor & $X$. exalbata & X. multiplex & \\
\hline H. tormentosum & $X$. feejeensis & $X$. obovata & \\
\hline
\end{tabular}

\section{Dendang pumpkin (Hodgsonia sp.)}

Most villagers from Suka Maju did not know the benefits of dendang pumpkin seed. However, in Air Besar Sub-district, Landak District, West Kalimantan, this fruit is called the gamang ghost fruit, a passion fruit-like plant but fruit such as pumpkin (Cucurbita moschata). This plant is easy to find around the riverside. Some residents consume these seeds by burning and the seeds have a slightly bitter taste. For Malaysian, dendang pumpkin is called the root of kepayang or kadam seed and pork lard plant.

There are many species of Hodgsonia (about forty species; Sahoo et al. 2014) including 2 species, namely Hodgsonia macrocarpa and $H$. heteroclyta. The species of $H$. heteroclyta are unknown but have economic value and as a medicinal plant in India. Therefore, in Semwal et al. (2014) mentioned that Hodgsonia in tropical forests of Asia is increasingly scarce due to exploitation for medicinal purposes. Talambedu et al. (2017) also reported that the $H$. heteroclyta fruit pulpy has the potential to be antidiabetic, and by Swargiary and Brahma (2017) also referred to having antioxidant activity.

For researchers from China, this plant has the potential to developed because it has high oil content and large seeds (Chien 1963). It is same as North India, according to Semwal et al. (2014), H. heteroclyta is a plant that has potential to be commercialized because of its high oil content. Furthermore, this oil is known as lard nut oil because it has seeds and the oil has taste like a lard. The oil 
content in dendang pumpkin seeds is $\pm 65 \%$ (dry weight) (Sugiyono 2008) and can reach $70 \%$ (Bo et al. 2007); $71.65 \%$ (dry weight) (Cao and Zhang 2015); 62-77\% (Semwal et al. 2014). based on (Bo et al. 2007) The highest content of fatty acids in Hodgsonia seed oil is linoleic acid. The type of fatty acid that is highest in corn oil (Carrillo et al. 2017). Therefore, this oil is often used as a substitute for coconut oil in India. Hodgsonia seed oil has the potential to be developed into biodiesel in Indonesia with $65 \%$ biodiesel yield from $H$. macrocarpa (Wirawan 2007), for biodiesel in China based on (Bo et al. 2007); 95.46\% (Cao and Zhang 2015).

Hodgsonia macrocarpa had been reported from East Kalimantan by Susiarti and Setyowati 2005). It was stated that there was dendang pumpkin in West Kalimantan, especially in Sambas. For the people of East Kutai, dendang pumpkin seeds are used as a flavoring. In addition, the citizens of southeast India also sell seeds for various dishes and medicine. For Thai people, the seeds are eaten by roasting until they release the aroma of lard or curry dishes, whereas in southeastern India the roasted seeds are made into chutney which is eaten with dried fish (Kharshandi et al. 2015) including for cakes and drinks (Semwal et al. 2014). In addition to seeds, fruit pulp is reported to reduce blood glucose level in mice that may be derived from antioxidant compounds which their contain (Talambedu et al. 2017). In 2007, when the researcher did survey it was mentioned that consuming raw Hogsonia seeds is not allowed, there were possible any side effects of it, but no one had tested the poisonous nature of the seeds to date (Schreiter et al. 2007). Thus, Hogsonia seeds should be preserved and developed because it can become a new alternative food from the Kapuas Hulu District.

Keranji mushroom (Hypoxilon sp.) the type of fungus of the genera Hypoxylon is still rarely analyzed qualitatively or quantitatively in publications related to native Indonesian fungi. Mushroom's shape is very small, the width about $1 \mathrm{~cm}$ with a shape like a keranji sour fruit, and having like a stick attached to the surface of the wood and a little hard but easy to cut. This type of fungus is found living on dead wood trunks with a rather moist environment and rarely exposed to sunlight. According to residents, young mushrooms that are still white are better than old mushrooms, because its cap is white with a nonhard texture while old ones have brown mushroom cap and the texture is rather hard. The residents consumed these mushrooms by washing, soaking them briefly and then sauteed or for vegetable soup ingredients. Some residents said that consuming the mushroom with excessive amounts, can make you drunk.

Table 3. Proximate nutrients of some wild plants, indigenous and edible biodiversity from Suka Maju and Tamao Villages, Kapuas Hulu District, West Kalimantan, Indonesia

\begin{tabular}{|c|c|c|c|c|c|c|c|}
\hline \multicolumn{2}{|c|}{ Plant diversity } & \multirow[b]{2}{*}{ Moisture (\%) } & \multirow[b]{2}{*}{$\operatorname{Ash}(\%)$} & \multirow{2}{*}{$\begin{array}{c}\text { Protein } \\
(\%)\end{array}$} & \multirow{2}{*}{$\begin{array}{l}\text { Fat } \\
(\%)\end{array}$} & \multirow{2}{*}{$\begin{array}{c}\text { Carbohydrate } \\
(\%)\end{array}$} & \multirow{2}{*}{$\begin{array}{c}\text { Calories } \\
\text { (kcal/g) }\end{array}$} \\
\hline Local name & Scientific name & & & & & & \\
\hline Dangkuk seeds & Hydnocarpus sp. & 2.15 & 6.49 & 22.17 & 34.92 & 34.27 & 540.03 \\
\hline Kepayang seeds & Pangium edule & 8.82 & 2.52 & 21.32 & 38.78 & 28.56 & 546.51 \\
\hline Jali seeds & Coix lacryma-jobi & 13.43 & 2.71 & 17.91 & 12.57 & 53.38 & 396.31 \\
\hline Kerantik seeds & Lepisanthes sp. & 51.76 & 5.5 & 4.98 & 1.45 & 36.31 & 194.73 \\
\hline White Abok & Ipomea cf. gracilis & 77.88 & 2.15 & 0.36 & 2.24 & 17.37 & 70.29 \\
\hline Buas-buas leaf & Premma cordiflora & 11.53 & 6.09 & 14.5 & 13.35 & 54.53 & 396.2 \\
\hline Sengkubak leaf & Albertisia papuana & 22.26 & 2.58 & 23.03 & 14.76 & 37.37 & 374.4 \\
\hline Patikala sour fruit & Etlingera elatior & 57.74 & 4.21 & 16.2 & 6.11 & 15.74 & 182.7 \\
\hline Bamboo shoots & Dendrocalamus latiflorus & 91.6 & 1.72 & 0.14 & 2.87 & 3.67 & 23.58 \\
\hline Mangkok mushroom & Cookeina sulcipes & 71.29 & 1.55 & 0.78 & 8.54 & 17.84 & 68.35 \\
\hline White mushroom & Pleurotus astreatus & 62.55 & 6.32 & 0.41 & 12.25 & 18.47 & 69.30 \\
\hline Golang mushroom & Lentinus sajorcaju & 14.91 & 2.88 & 3.81 & 12.21 & 66.19 & 178.76 \\
\hline Keranji mushroom & Hypoxylon spp. & 8.81 & 7.64 & 4.24 & 12.32 & 66.99 & 167.39 \\
\hline Tawon mushroom & Schizophyllum commune & 13.44 & 4.71 & 3.64 & 16.86 & 61.35 & 201.25 \\
\hline Litakan fruit & Willughbeia angustifolia & 74.3 & 0.22 & 4.26 & 20.39 & 0.83 & 203.86 \\
\hline
\end{tabular}

Table 4. Mineral content of some wild plants, indigenous and edible biodiversity from Suka Maju and Tamao Villages, Kapuas Hulu District, West Kalimantan, Indonesia

\begin{tabular}{|c|c|c|c|c|c|c|c|c|c|}
\hline \multicolumn{2}{|r|}{ Plant diversity } & \multicolumn{8}{|c|}{ Minerals } \\
\hline Local name & Scientific name & $\begin{array}{c}\mathbf{P} \\
(\%)\end{array}$ & $\underset{(\%)}{K}$ & $\begin{array}{l}\mathrm{Na} \\
(\%)\end{array}$ & $\begin{array}{l}\mathrm{Ca} \\
(\%)\end{array}$ & $\begin{array}{l}\mathrm{Mg} \\
(\%)\end{array}$ & $\begin{array}{c}\mathbf{F e} \\
(\mathbf{p p m})\end{array}$ & $\underset{(\mathbf{p p m})}{\mathbf{C u}}$ & $\begin{array}{c}\mathbf{Z n} \\
(\mathbf{p p m})\end{array}$ \\
\hline Engkala fruit & Litsea garciae & 0.43 & 0.87 & 0.04 & 0.08 & 0.01 & 30.77 & 0.42 & 9.35 \\
\hline Sengkuang fruit & Dracontomelon dao & 0.23 & 03.4 & 0.19 & 0.33 & 0.19 & 934.33 & 18.36 & 14.75 \\
\hline Aratak binung & Abelmoschus esculentus & 2.08 & 3.28 & 0.16 & 0.39 & 0.2 & 99.34 & 21.11 & 51.24 \\
\hline Tepus leaf & Eringium foetidum & 0.74 & 2.48 & 0.13 & 0.29 & 0.26 & 14.61 & 14.61 & 231.89 \\
\hline Lepang fruit & Gymnopetalum cochinensis & 1.41 & 2.01 & 1.56 & ud & 0.08 & 13.94 & ud & 30.23 \\
\hline
\end{tabular}

Note: ud: undetected 
Hypoxylon type wasfound physically similar to Xylaria schweinitzii found in Bosque Húmedo Tropical Amazónico National Park, Bosque Piemontano Occidental, Bosque Montano Oriental, Equador or similar to Xylaria fockei from Thailand. Between the genera, Hypoxylon and Xylaria are very closely related because they are both in one order, Xylariales. Hypoxylon/Xylaria is a fungus ascomycete, including large fungi (macrofungi). A comparison of these two types of mushrooms with keranji mushrooms can be seen in Figure 5. The results of research related to Hypoxylon from Indonesia, Biscogniauxia nummularia var. pseudopachyloma with the synonym name Hypoxylon pseudopachyloma $=H$. nummularium found in Java. The $H$. tortysporum species is said to originate from the North Sulawesi, Indonesia (Hellwig et al. 2005). According to Smith and Hyde (2001), it is said a species similar to Hypoxylon was found in Indonesia (northern Sulawesi) under the name $H$. kretzschmaria, and $H$. maculosum. The Indonesian Ministry of Forestry also reported to FAO that Entoleuca mammata with another Latin name of Hypoxylon mammatum / $H$. pauperatum / H. morsei / H. blakei / H. holwayi is found in Indonesia's forests. This type of Hypoxylon canker is known as a black stem canker (FAO 2007). Hypoxylon lenormandii is also called in (Kuhnert et al. 2015) originated from Indonesia. Hypoxylon growth is reported in the dry season more commonly found in Nigerian tropical forests in lignin-rich habitats (Adeniyi et al. 2018). Hypoxylon oceanicum has been reported by Jones and Kuthubutheen (1989) is a type of Hypoxylon that grows in mangrove areas. Hypoxylon publications from Indonesia in 1980-2017 showed that no explanation Hypoxylon existed from West Kalimantan.

When compared with Hypoxylon, many reports from Indonesia about Xylaria (Yulianti 2017; Li et al. 2017) are similar due to the nature of essence of xylariousousness' which is found in many tropical regions (Rogers et al. 1987). Sunariyati et al. (2016) also reported the results of his research that found Xylaria sp. in Central Kalimantan as the karamu fungus used as a cancer drug. Besides that, $X$. polymorpha was also found in Central Kalimantan (Noor and Saridan 2013). Type X. polymorpha and X. tabacina described are types of Xylaria that live on dead wood and can be eaten from East Kalimantan (Mardji and Noor 2009). Based on the research results about Xylaria in Indonesia there are no publications related to $X$. schweinitzii or X. fockei from Indonesia. Linh et al. (2014) mentioned that $X$. schweinitzii from Vietnam's national park has activities as an anticancer. A similar report from Thailand also mentioned the type of fungus Xylaria spp showed antibacterial and anticancer activities but it was not specifically mentioned the name of the species except as Xylaria code TR25 (Orachaipunlap et al. 2015). Type $X$. fockei is also found in Mexico (Medel et al. 2010), Papua including Sabah (Dennis 1974), Equador and Puerto Rico (Lodge 2008).

\section{Proximate, calories and minerals}

Based on Table 2, the highest protein source is from sengkubak /tugu leaves, dangkuk and kepayang with an average level $>20 \%$. The highest source of fat comes from dangkuk seed, kepayang, and litakan fruit, with an average level > 20\%. According to Ayu et al. (2017) and Atabani et al. (2015), kepayang seeds can produce vegetable oils meanwhile Hoe and Siong (1999) has been reported that the fat content of $P$. edule from Sarawak was $20.2 \%$. Fat content of litakan fruits is reported for the first time from this research result and no reported about it until now except about the rubber-like latex (Lim et al. 2012). From Table 2 too, it showed that the higher of fat and the higher of carbohydrate as the higher of the calories.

The sources of carbohydrates with levels> 50\% are joli kusuk (jali) and mushrooms especially keranji, golang and tawon. According to Grubben and Partohardjono (1996), the range carbohydrate content of jali $(C$. jobi) are between 58.3 until 77.2 , so that the carbohydrate of $C$. jobi from Kapuas Hulu district was lower. We think the lower content because the plant is wild that there is no added fertilizer. The higher fiber from mushrooms because generally edible mushrooms are rich in polysaccharides that some of them were fiber (Cheung 2013). According to Vázquez et al. (2018), Hipoxylon sp. is rich in lignin which is fiber. Those cases due to jali and mushroom reserves are a source of food, especially as dietary fiber. There is connection between sources of higher fat

In conclusion, there are 98 types of plant diversity, wild plants and native edible plants in Suka Maju Village, Mentebah District and Tamao Village, Embaloh Hulu District, at Kapuas Hulu Regency. Based on the calories content and mineral the plants that have potential to be developed as a food, medicine or industrial are joluk kusuk seeds (Coix lacryma jobii), kepayang seeds (Pangium edule), dangkuk seeds (Hodgsonia sp.), dendang pumpkin seeds (Hydnocarpus sp.), tugu/sengkubak leaves (Albertisia papuana), tepus leaves (Eryngium foetidum), sengkuang fruits (Dracontomelon dao). Types of plant diversity that unknown from West Kalimantan and found in Kapuas Hulu Regency are Hodgsonia sp., Hydrocarpus sp. and Hypoxylon spp. According to the results from this survey, it is expected that the Agriculture and the Forestry Agency of Kapuas Hulu Regency will begin to socialize the importance of local wisdom in supporting national food security, and prioritize the development of local food sources became economic sources of the community through further research related to potential development into commercial products.

\section{ACKNOWLEDGEMENTS}

The team of authors would like to thank The Food Agency of West Kalimantan Province in 2018 for funding a survey of biodiversity, edible and wild species so that the data referred to in this article can be obtained. 


\section{REFERENCES}

Adeniyi M, Odeyemi Y, Odeyemi O. 2018. Ecology, diversity and seasonal distribution of wild mushrooms in a Nigerian tropical forest reserve. Biodiversitas 19: 285-295. [Indonesian]

Angriyanti L. 2010. Etnobotani dan potensi tumbuhan berguna di Kampung Keay, Kabupaten Kutai Barat, Kalimantan Timur. IPB, Bogor. [Indonesian]

AOAC. 2006. Official Methods of Anal y sis of AOAC International. In: Horwitz W, Lalimer GW (eds). AOCA International, USA.

Atabani AE, Masjuki HH, Chong WT, Lee KT, Badruddin AJ. 2015 Pangium edule Reinw: A Promising Non-edible Oil Feedstock for Biodiesel Production. Arab J Sci Eng 40: 583-594

Ayu DF, Man YC, Rohman A. 2017. Chemical Properties, Fatty Acid Composition, and Lipid Profiles of Picung (Pangium edule Reinw) Kernel Oil from Riau Province. Appl Sci Technol 1: 42-46.

Bo M. Chun-lin L, Zhi-ying C, Yuan LIU. 2007. Development Strategy for a Biodiesel Plant, Large-fruited Hodgsonia. North Hortic 2: 30430

BPS Kabupaten Kapuas Hulu. 2018. Kapuas Hulu Dalam Angka Tahun 2014- 2018. Badan Pusat Statistik Provinsi Kalimantan Barat, Pontianak. [Indonesian]

BPS Kapuas Hulu. 2019. Kecamatan Mentebah Dalam Angka 2019. Badan Pusat Statistik Kabupaten Kapuas Hulu. [Indonesian]

Cao L, Zhang S. 2015. Production and characterization of biodiesel derived from Hodgsonia macrocarpa seed oil. Appl Energy 146:135140

Carrillo W, Carpio C, Morales D, Vilcacundo E, Álvarez M, Silva M. 2017. Content of fatty acids in corn (Zea mays L.) oil from Ecuador. Asian J Pharm Clin Res10: 150-153.

Cheung PCK. 2013. Mini-review on edible mushrooms as source of dietary fiber: Preparation and health benefits. Food Sci Hum Wellness me 2: $162-166$

Chien H. 1963. "Lard fruit" domesticated in China. Euphytica12: 261262.

Cole HI. 1933. Chemistry of' leprosy drugs. Int J Leprosy 1: 159-194

Dennis RWG. 1974. Xylariaceae from Papua and New Guinea. Bull Mensuel de La Société Linnéenne de Lyon 43:127-138.

de Wilde WJJO, Duyfjes BEE. 2010. Flora Malesiana. Series I, Seed plants. Vol 19: Cucurbitaceae. National Herbarium Nederland, Leiden

Dhanasekaran M, Karuppusamy S, Annadurai M, Rajasekaran K. 2013. Evaluation of Phytochemical Constituents of Indian Medicinal Plant Hydnocarpus alpina WIGHT. Indian J Pharm Biol Res 1: 23-28.

Dhathri NR. 2011. Biochemical Characterization of Hydnocarpus pentandra for Seed Oil Quality, Oil Cake and Its Biodiesel Production Potential 3-5.

FAO. 2007. Forest Health \& Biosecurity Working papers, Overview of Forest Pests. FAO, Rome.

Grubben GJH, Partohardjono S. 1996. Plant Resources of South-East Asia No. 10: Cereal. PROSEA Foundation, Bogor. Backhuys Publ., Leiden.

Haryanti ES, Diba F, Wahdina. 2015. Etnobotani tumbuhan berguna oleh masyarakat sekitar kawasan kph model Kapuas Hulu. Jurnal Hutan Lestari 3: 434-445. [Indonesian]

Hellwig V, Ju Y.-M, Rogers JD, Fournier J, Stadler M. 2005. Hypomiltin, a novel azaphilone from Hypoxylon hypomiltum, and chemotypes in Hypoxylon sect. Hypoxylon as inferred from analytical HPLC profiling. Mycol Prog 4: 39-54.

Hoe VB, Siong KH. 1999. The nutritional value of indigenous fruits and vegetables in Sarawak. Asia Pac J Clin Nutr 8:24-31

Jones E, Kuthubutheen A. 1989. Malaysian mangrove fungi. Sydowia 41 $160-169$

Kartawinata K, Priyadi H, Sheil D, Riswan S, Sist P, Machfudh. 2006. A field guide to the permanent sample plots in the reduced-impact logging block 27 at CIFOR Malinau research forest East Kalimantan. In: A field guide to the permanent sample plots in the reduced-impact logging block 27 at CIFOR Malinau research forest East Kalimantan. Bogor. [Indonesian]

Kekuda P, Kenie D, Chetan D, Raghavendra H. 2017. Phytochemical analysis, antimicrobial, the insecticidal and antiradical activity of Hydnocarpus pentandra (Buch.-Ham.) Oken. Int J Phytomed 9: 576.

Kharshandi D, Lyngdoh D, Bokolia D. 2015. Minor fruits used by locals in two hill districts of Meghalaya, northeast India. Asian J Pharm Bio Res (AJPBR) 5: 1-15.
Kuhnert E, Surup F, Sir EB, Lambert C, Hyde KD, Hladki AI, Stadler M. 2015. Lenormandins $\mathrm{A}-\mathrm{G}$, new azaphilones from Hypoxylon lenormandii and Hypoxylon jaklitschii sp. nov., recognized by chemotaxonomic data. Fungal Divers 71: 165-184.

Lee S, Jones EGBA, Zainudin N. 2012. Checklist of Fungi of Malaysia. http://www.ghbook.ir/index.php?name= رسانه هاينوين\&option=com_dbook\&task=readonline\&book_id=13650\&page =73\&chkhashk=ED9C9491B4\&Itemid=218\&lang=fa\&tmpl=compon ent

Li Q, Liu L, Zhang X, Shen X, Kang J. 2017. Xylaria spinulosa sp. nov. and X. atrosphaerica from southern China. Mycosphere 8: 1070-1079

Lim TK. 2012. Willughbeia angustifolia. Edible Med Non-Med Plants 1: 47-48

Linh DTP, Hien BTT, Que DD, Lam DM, Arnold N, Schmidt J, Quan DN. 2014. Cytotoxic constituents from the Vietnamese fungus Xylaria schweinitzii. Nat Prod Commun 9: 659-660

Lodge D. 2008. Montane and cloud forest specialists among neotropical Xylaria species. North Am Fungi 3: 193-213

Mardji D, Noor M. 2009. Keanekaragaman jenis jamur makro di Hutan Lindung Gunung Lumut. Jurnal Kehutanan Tropika Humida 2: 143155. [Indonesian]

Medel R, Uzman G, Castillo R. 2010. Adiciones al conocimiento de. Revista Mexicana De Micologia 31: 9-18.

Nayasilana IN, Hadisusanto S, Wijayanto H, Atmoko SSU, Prasetyo D, Sihite, Van Schaik CP. 2017. Behavioral ecology of reintroduced orangutans in the Bukit Batikap, Central Kalimantan, Indonesia. Biodiversitas 18: 875-886. [Indonesian]

Noor M, Saridan A. 2013. Keanekaragaman fungi makro pada tegakan benih Dipterocarpaceae di Taman Nasional Tanjung Puting dan Taman Nasional Sebangau, Kalimantan Tengah. Jurnal Penelitian Ekosistem Dipterokarpa 7 (1): 53-62. [Indonesian]

Orachaipunlap K, Suwannasai N, Whalley AJ. 2015. Antibacterial and Anticancer Activity of Stromatic Xylaria spp. from Tropical Forest Thailand. KMITL Sci Tech J 15: 1-9

Parascandola J. 2003. Chaulmoogra Oil and the Treatment of Leprosy. Pharm Hist 45: 47-57

Peraturan Presiden RI Nomor 21 Tahun 2018 Tentang Strategi Nasional Percepatan Pembangunan Daerah Tertinggal Tahun 2015-2019. [Indonesian]

PERDA Kabupaten Kapuas Hulu No. 20. 2015. Penetapan Kabupaten Kapuas Hulu Sebagai Kabupaten Konservasi. [Indonesian]

Pradityo T, Santoso N, Zuhud EA. 2017. Ethnobotany Di Kebun Tembawang Suku Dayak Iban, Desa Sungai Mawang, Kalimantan Barat. Media Konservasi 21: 183-198. [Indonesian]

Purwayantie. 2019. Pengantar Tren Pangan Global Menuju 2050. TOP Indonesia, Pontianak. [Indonesian]

Rameshkumar KB, Hishan A, Latha PG. 2011. Chemistry and therapeutic potential of chaulmoogra oil. RPMP 33: 339-356

Rogers J, Callan B, Samuels G. 1987. The Xylariaceae of the rain forests of North Sulawesi (Indonesia). Mycotaxon 29: 113-172.

Sahoo MR, Dhanabal SP, Jadhav AN, Reddy V, Muguli G, Babu UV, Rangesh P. 2014. Hydnocarpus: An ethnopharmacological, phytochemical and pharmacological review. J Ethno Pharmacol 154: $17-25$

Satrima R, Lovadi I, Linda R. 2015. This research aimed to find out the types, parts of plant organ, processing methods and categories of utilization of food plants in the Malay Community of Boyan Tanjung Village, Kapuas Hulu Regency. Protobiont 4: 90-95.

Schreiter, Langenberger GJ, Heller J, Margraf J. 2007. Hodgsonia heterolica (Roxb.) Hook.f. \& Thomson (Cucurbitaceae)-a neglected oil plant in Southwest China. Tropentag 2007 University of KasselWitzenhausen and University of Göttingen, October 9-11, 2007 Conference on International Agricultural Research for Development.

Semwal DP, Bhatt KC, Bhandari DC, Panwar NS. 2014. A note on distribution, ethnobotany and economic potential of Hodgsonia heteroclita (Roxb.) Hook. f \& Thoms. in North-eastern India. Indian J Nat Prod Resour 5: 88-91.

Smith GJD, Hyde KD. 2001. Fungi from palms. Astrocystis, Biscogniauxia, Cyanopulvis, Hypoxylon, Nemania, Guestia, Rosellinia and StilboHypoxylon XLIX. Fungal Divers. http://www.fungaldiversity.org/fdp/sfdp/FD_7_89-127.pdf

Subramanian R, Gayathri S, Rathnavel C, Raj V. 2012. Analysis of mineral and heavy metal levels nutrients in medicinal plants collected from local market. Asian Pacific J Trop Biomed 1-5

Sudarmadji S, Haryono B, Suhardi. 2007. Analisa Bahan Makanan dan Pertanian. Liberty Yogyakarta, Yogyakarta. [Indonesian] 
Sugiyono A. 2008. Peluang Pemanfaatan Biodiesel dari Alternatif Pengganti Minyak Solar. Prospek Pengembangan Bio-Fuel sebagai Substitusi Bahan Bakar Minyak 29-40. [Indonesian]

Suhartini. 2009. Peran konservasi keanekaragaman hayati dalam menunjang pembangunan yang berkelanjutan. Prosiding Seminar Nasional Penelitian, Pendidikan dan Penerapan MIPA. B199-B-205. [Indonesian]

Sukasih E, Setyadjit N. 2017. Formulasi Pembuatan Flake Berbasis Talas Untuk Makanan Sarapan (Breakfast Meal) Energi Tinggi Dengan Metode Oven. Jurnal Penelitian Pascapanen Pertanian 9: 70-76. [Indonesian]

Sunariyati S, Frantika A, Purnaningsih T. 2016. Studi Etnomikolog Pemanfaatan Jamur Karamu (Xylaria sp.) sebagai Obat Tradisional Suku Dayak Ngaju di Desa Lamunti Karakteristik Jamur Karamu (Xylaria sp). Proc Biol Educ Conf 13: 633-636. [Indonesian]

Susiarti S, Setyowati FM. 2005. Traditional spices of Dayak Kenyah society in East Kalimantan. Biodiversitas 6: 285-287. [Indonesian]

SwargiaryA, Brahma D. 2017. Phytochemical analysis and antioxidan activity of Hodgsonia heteroclita (Roxb). Indian J Pharm Sci 79: 212219
Talambedu U, Middha SK, Narzary D, Brahma BK, Goyal AK. 2017. In silico and in vivo based evaluation of traditional antidiabetic herb Hodgsonia heteroclita. Bangladesh J Pharmacol 12: 165-166

Tallo AJ. 2018. Participatory Village Spatial Planning in Efforts to Save Conservation Areas in Mantan village, Semitau Sub-district, Kapuas Hulu District. J Phys: Conf Ser 1114 (2018) 012050.

Varghese B, Sandhya S, Kavitha M, Krishnakumar K. 2016. Genus Hydnocarpus: A Review. Int J Phytopharmacol 7: 143-154

Vázquez MA, Cabrera ECV, Aceves MA, Mallol JLF. 2019. Cellulolytic and ligninolytic potential of new strains of fungi for the conversion of fibrous substrates. Biotechnol Res Innov 3(1): 177-186.

Wibowo A, Karsidi R, Sudardi, B, Wijaya, M. 2019. Economic glocalization: A sustainable local food production system in Wonosobo Indonesia. IOP Conf Ser: Mater Sci Eng 633 (2019) 012059 .

Wirawan SS. 2007. Future Biodiesel Research Asian Science and Technology Seminar. Asian Sci Technol Semin, (March). http://www.jst.go.jp/asts/asts_j/files/ppt/16_ppt.pdf

Yulianti T. 2017. Perkembangan penyakit lapuk akar dan pangkal batang tebu (Xylaria warbugii) di Sumatera dan strategi pengendaliannya. Perspektif 16: 122-133. [Indonesian] 